\title{
How Chilean Journalists Use Social Media: Digital Transformation and New Forms of Visibility and Identity Creation*
}

Claudia Mellado ${ }^{1}$ Auska Ovando²

Recibido: $13 / 01 / 2020$

Aprobado por pares: 03/02/2020
Enviado a pares: $13 / 01 / 2020$

Aceptado: 01/03/2020

DOI: 10.5294/pacla.2021.24.2.2

Para citar este artículo / to reference this article / para citar este artigo Mellado, C. y Ovando, A. (2021). How Chilean Journalists Use Social Media: Digital Transformation and New Forms of Visibility and Identity Creation. Palabra Clave, 24(2), e2422. https://doi.org/10.5294/pacla.2021.24.2.2

\section{Abstract}

Based on the content analysis of 1,400 Twitter and Instagram accounts, this study identified the social media profiles of 792 Chilean journalists from national media outlets to describe their visibility and activity levels and how they construct their identities. Our results show that although Chilean journalists have a solid digital presence, they use social media platforms differently, displaying various identity creation strategies and new journalistic roles. Our findings also address the media outlets' influence on Chilean journalists' profiles, level of use, and the identities emerging from their social media accounts.

\section{Keywords (Source: Unesco Thesaurus)}

Journalism; journalists; social media; Twitter; Instagram; Chile.

\footnotetext{
Funding: This work was supported by Chile's National Fund for Scientific and Technological Development (Fondo Nacional de Desarrollo Científico y Tecnológico [FONDECYT]; Grant Number 1180443).

$1 \bowtie$ https://orcid.org/0000-0002-9281-1526. Pontificia Universidad Católica de Valparaíso, Chile. claudia.mellado@pucv.cl

2 https://orcid.org/0000-0001-7468-540X. Pontificia Universidad Católica de Valparaíso, Chile.
} 


\section{Periodistas y redes sociales en Chile: transformación digital y nuevas formas de visibilidad y creación de identidad*}

\section{Resumen}

Con base en un análisis de contenido de 1400 cuentas de Twitter e Instagram de 792 periodistas de medios nacionales chilenos, este estudio buscó identificar los diferentes perfiles que los periodistas dan a sus cuentas en las redes sociales mencionadas, describir su visibilización y niveles de actividad y analizar la construcción de identidad que estos generan en ambas redes. Los resultados muestran que, aunque los periodistas chilenos tienen una alta presencia en el mundo digital, dan un uso diferenciado a cada red, lo cual despliega distintas estrategias de creación de identidad, así como la emergencia de nuevos roles periodísticos. Al mismo tiempo, los hallazgos revelan la influencia que el tipo de medio en que los periodistas se desempeñan tiene en los perfiles, usos e identidades que emergen desde sus cuentas.

\section{Palabras clave (Fuente: tesauro de la Unesco)}

Periodismo; periodistas; redes sociales; Twitter; Instagram; Chile.

* Financiación: el presente trabajo contó con el apoyo del Fondo Nacional de Desarrollo Científico y Tecnológico [FONDECYT], número de subvención 1180443. 


\section{Jornalistas e redes sociais no Chile: transformação digital e novas formas de visibilidade e criação de identidade*}

\section{Resumo}

Com base numa análise de conteúdo de 1.400 contas do Twitter e do Instagram, de 792 jornalistas de meios nacionais chilenos, neste estudo, buscou-se identificar os diferentes perfis que os jornalistas dão a suas contas nas redes sociais mencionadas, descrever sua visualização e níveis de atividade, e analisar a construção de identidade que eles geram em ambas as redes. Os resultados demonstram que, embora os jornalistas chilenos tenham alta presença no mundo digital, dão uso diferenciado a cada rede, o que pode levar a diferentes estratégias de criação de identidade, bem como à emergência de novos papéis jornalísticos. Ao mesmo tempo, os achados revelam a influência que tem o tipo de meio em que os jornalistas se desempenham nos perfis, nos usos e nas identidades que emergem a partir de suas contas.

\section{Plavras-chave (Fonte: tesauro da Unesco)}

Jornalismo; jornalistas; redes sociais; Twitter; Instagram; Chile.

* Este trabalho foi financiado pelo Fondo Nacional de Desarrollo Científico y Tecnológico com o número 1180443. 


\section{Introduction}

Social media platforms have created a new media ecosystem, changing how journalists work, shape their identities, and introduce themselves to their audiences (Grubenmann \& Merckel, 2015). Over the past several years, their popularity has grown exponentially, and they are now used all over the world. Tools such as Twitter, Facebook, and Instagram are increasingly integrated into communication structures and communication processes among people, particularly those employed by journalists (Van Dijck, 2013).

Because of their open and horizontal nature and their capacity to facilitate real-time conversation, social media platforms have profoundly impacted the construction of public discourse. News travels faster than ever, and the privileged position that journalists used to hold to inform their audiences has changed (Mellado \& Van Dalen, 2017). Journalists are no longer merely the authors of news stories or the face of newscasts. Today, they must be accessible to their audiences and willing to engage in conversation and digital relationships mediated by social media (Hedman, 2016). In a context where the public-private sphere is increasingly complex, today's journalists must craft their images and identities using platforms such as personal social media accounts.

Hundreds of studies have analyzed various aspects of the relationship between journalism and the digital world, such as the impact of social media on newsroom routines (Hermida, 2010; Noguera-Vivo, 2013) and the use of social media by journalists, particularly those with the most followers or the most influential in a particular field or topic (Gulyas, 2013; Hermida, 2013; Holton \& Lewis, 2011; Lasorsa et al. 2012; Olausson, 2017). However, markedly fewer efforts have been made to map journalists' social media use and profiles, at least in Latin America. The studies conducted tend to be based on surveys and interviews about newspeople's perceptions but have not analyzed their practices (Mourao \& Harlow, 2017; Powers \& Vera-Zambrano, 2017; Saldaña et al., 2017; Weiss, 2015). Moreover, studies centered on journalistic practices in social media, and not just the perceptions and discourses built around them, have usually analyzed just one platform, such as Twitter (Hermida, 2013). 
This study focuses on two digital platforms - Twitter and Instagram - that offer users different functionalities and feature objective qualities in terms of their narratives, textual-visual logics, and how they approach audiences, despite sharing specific mechanisms for facilitating user communication (Hermida \& Mellado, 2020). The main goal of this study is twofold. On the one hand, we are interested in exploring the Twitter and Instagram profiles of journalists who work in Chilean national media and describing how they introduce themselves to their audiences and their activity levels on both platforms. On the other hand, we analyze the journalists' identity construction (whether personal or organizational) in a context where their profession and the media outlets they work for are increasingly questioned and losing credibility (Edelman, 2019).

The focus is placed on the journalist as a medium represented by their Instagram or Twitter accounts and not their media outlets. Journalists ${ }^{\prime 3}$ performance on social media has become an essential subject matter due to the mediatization of contemporary societies and how media logics are gaining an increasingly dominant presence in social and individual lives. How these professionals engage in these communication platforms speaks to both individual expressions of a particular link to technology and how information is transmitted and validated in Chilean society.

\section{The digital transformation of journalists on social media}

While the literature shows that journalists are incorporating social media into their professional and personal lives (Brems et al., 2017), it also suggests that it is hard, but not impossible, to observe how journalists use their accounts (Powers \& Vera-Zambrano, 2017).

So far, most of the studies have focused on how journalists include social media in their journalistic routines within and beyond the institutional media in which they work, such as cross-checking information on Twitter or Instagram, promoting the content that they have created, and posting about public events or their personal lives. In this sense, social media have emerged as a critical tool for practicing modern journalism and a different

3 Based on Mellado et al. (2010), we define journalists as media professionals (whether they have university training) who are paid to create content for news organizations. Note that journalism is a highly professionalized field in Chile. The latest statistics show that 9 out of 10 journalists hold an undergraduate degree in their field (Mellado, 2012). 
means by which journalists create their brand (Brems et al., 2017; Hermida, 2010; Hermida \& Mellado, 2020).

Accordingly, scholars have begun to theoretically explore the functionalities associated with the affordances of each platform, as they shape both how news professionals use their social media accounts and the content they create in terms of aesthetics, genre conventions, rhetorical practices, interactive mechanisms, and the emergence of new professional roles (Hermida \& Mellado, 2020; Mellado \& Hermida, 2021).

A survey of 877 Latin American journalists conducted by Saldaña et al. (2017) focused on perceived social media use. The study revealed that $80 \%$ of journalists had a personal Twitter account, but only $24 \%$ had a personal Instagram account. Twitter was found to be an essential platform for daily news-gathering and journalistic work. Journalists also reported that they mainly use social media to stay current and find ideas and sources for their stories. Journalists also stated that they were less likely to use the platforms for entertainment or distraction. Other studies have also found that journalists use their social media accounts to build an identity and engage with virtual audiences.

Gulyas (2013) studied journalists' social media use in Finland, Germany, United Kingdom, and Sweden and found that although the intensity of use varied, $96 \%$ of those surveyed used social media platforms to do their jobs in any given week. British journalists were the most avid social media users and had the most positive attitudes towards these platforms. The findings also revealed that newsroom size and career length did not impact journalists' social media use and that the type of media outlet where they worked did shape social media use in the UK and Finland, where print journalists used fewer social media platforms than their TV and online colleagues.

Mourao and Harlow (2017) examine Brazilian journalists' social media use in a survey of 1,250 reporters. Their results suggest that the respondents' three primary purposes for Instagram and Twitter were to stay current on the news, report, and develop a brand. Brazilian journalists also stated that they use Instagram (72.5\%) more than Twitter (67.1\%). 
Tandoc and Vos (2016) use non-participant observation and in-depth interviews to analyze how 31 journalists in three different digital newsrooms in the US use social media in their work. Their results show that web editors mainly use Twitter and Facebook, although they also upload pictures to Instagram and Pinterest. They also found that journalists normalize social media use while negotiating some of their traditional routines, knowing that they must market the news. For example, their study revealed that journalists try to balance their editorial autonomy with the public's growing influence, evolving the gatekeeper concept.

Also using qualitative techniques, Powers and Vera-Zambrano (2017) analyze American and French journalists' use of their social media accounts and find that in addition to daily tasks such as gathering information, getting in touch with sources, and developing story ideas, they use them to gain recognition among their peers. Specifically, their study shows that while US journalism encourages media professionals to target their social media presence towards audiences at an individual level, French journalism promotes social media for organizational purposes.

Ottovordemgentschenfelde (2017) notes that a person's presence on social media implicitly and inevitably influences certain types of branding. In journalists, it is possible to identify at least three types of identities associated with different kinds of branding. The first is organizational identity, which reflects the journalist's institutional affiliation. The second is professional identity, linked to occupational ideals and a sense of belonging to the profession. Lastly, personal identity shows the journalist's personality traits or personal information associated with affective elements.

\section{Materials and methods}

Given the absence of a current census of Chilean journalists ${ }^{4}$ and thus no reliable database of their social media accounts, we first studied the social media presence of all journalists working for Chilean leading national media organizations through an intense inquiry process conducted by the re-

4 The most recent census of journalists in Chile was conducted in 2010 (Mellado, 2012). It showed that most Chilean news is generated by young males with an undergraduate degree. 
search team over four months. Though we initially addressed the profiles of the country's most influential journalists (those with the most followers), we realized that this approach would limit our study to a small number of professionals, mainly those who work for newscast organizations. We thus decided to create a list of the journalists who work for the country's leading national media outlets, including those who hold different positions and perform various functions in their newsrooms.

We chose a single timeframe (2019), sample unit (media outlet), and unit of analysis (Twitter or Instagram profile) to make the data comparable. The team first identified the country's most prominent national media outlets. We then created a database of all reporters, editors, hosts, and journalists who create content for those outlets. This information was collected with the active cooperation of those journalists and the media organizations included in this study. We then used that information to find their Twitter and Instagram accounts. We coded several aspects, including the existence and privacy status of each account, the information in the journalists' biographies, their profile pictures, and their use of different functionalities and affordances offered by these platforms.

Two research assistants accessed each account and coded each profile using the codebook designed for this purpose. The corpus of units of analysis was divided randomly into the two coders such that each coded different types of accounts to reduce potential biases.

Several pretests were conducted before starting the coding process to ensure a similar understanding of the instrument. When the process was complete, we performed a post-test based on $5 \%$ of the total sample to calculate global intercoder reliability. Based on Krippendorff's alpha (Ka), final intercoder reliability ranges between .76 and .83 .

Four main elements were measured in each social media platform: the journalist's general profile (gender, media type, level of activity, popularity, use of affordances), visibility and identity construction (existence and content of profile pictures and bios, number of verified and business accounts, use of specific affordances such as geolocation, links, hashtags, 
Insta stories, Instagram TV, and banners), levels of personal and professional identities (connection to the profession made explicit in profile pictures and biographies, identification with news beats, openness to audience interaction), and organizational identity (identification of news media organizations in their profile pictures or biographies, their position inside those organizations, among others).

The census, profile list, and account coding were conducted between April and October 2019. We registered a total of 859 journalists from 39 national media outlets. ${ }^{5}$ Of these, $91.5 \%$ had an active account on Twitter, Instagram, or both platforms. In the end, 1,400 profiles from 792 journalists were analyzed.

\section{Results}

\section{Journalistic profiles on Twitter and Instagram}

Journalists who work for Chilean national media outlets have a significant presence in the digital world. The data reveal that $76.8 \%$ of the journalists included in the study have active accounts on both Twitter and Instagram. They also show that $21.5 \%$ use Twitter only and $1.7 \%$ use Instagram only. Most journalists' Twitter accounts ${ }^{6}$ were created between 2009 and 2010 (63.6\%), though variations were observed depending on the type of media for which they work. Those in online media, radio, and especially television tend to have engaged with Twitter earlier than their print media colleagues $\left(X^{2}=64.909 ; d f=12 ; p=.01\right)$.

Regarding privacy, the results show that while $97.7 \%$ of journalists' Twitter accounts are public, only $45.5 \%$ of Instagram accounts can be accessed by any user, which is the first indicator of how journalists employ

5 Outlets:

TV: Canal 13, CDF, Chilevisión, CNN Chile, Fox Sports, Mega, TVN/24 Horas

Radio: ADN, Agricultura, Bío-Bío, Concierto, Cooperativa, Duna, El Conquistador, Futuro, Imagina, Infinita, La Clave, Pauta, Sonar, T13 Radio, Universidad de Chile, Universo

Online media: El Desconcierto, El Dínamo, El Mostrador, Emol

Print media: Cambio 21, Diario Financiero, El Ciudadano, El Mercurio, La Cuarta, La Hora, La Segunda, La Tercera, LUN, Publimetro, The Clinic, Revista Capital

6 Account creation dates were not listed for Instagram because the platform does not provide access to this information. 
each tool. The data show that they tend to use Twitter to engage with different audiences and address their Instagram activity to a more limited audience based on personal connections and preferences.

The data also show that gender does not play a key role in shaping differences in Chilean journalists' presence on each platform. While active Twitter and Instagram accounts are maintained mainly by male journalists $(60.7 \%)$, this fact is due to the composition of the field and aligns with the gender distribution described in previous analyses of the profession (Mellado et al., 2010). Gender distribution is similar on Twitter and Instagram. Proportionally, 9 out of 10 men and 8 out of 10 women have a Twitter account (99 and $97.1 \%$ ) and an Instagram account (77.1 and $80.7 \%$ ), respectively.

Our analysis yielded similar results for differences in the journalists' presence on social media depending on the type of outlet in which they work. While many journalists with active accounts work in print media $(33.1 \%)$, TV $(29.1 \%)$, radio (26.1\%), and to a lesser degree in online media $(10.9 \%)$, this proportional difference coincides with the general labor structure of the profession (fewer journalists are working for online media outlets).

Even though the presence of Chilean journalists on social media is like, and in some cases even more significant than, that of journalists working in developed countries -Willnat and Weaver (2018), for example, found that 8 out of 10 journalists working in the US use social media in their daily work-, the popularity of Chilean journalists is incipient.

Also, the data show that the number of followers is quite heterogeneous on both social media platforms. Four out of 10 national journalists in Chile have fewer than one thousand followers on Twitter (39.9\%), and 6 out of 10 have an audience of this size on Instagram (64.9\%). Most Chilean journalists have between 1,000 and 10,000 followers on Twitter (43.3\%), but this is true for only $22.8 \%$ of them on Instagram. Meanwhile, only $6.6 \%$ of journalists on Twitter and $2.7 \%$ on Instagram have over 50,000 followers. The 
most popular journalists on Twitter have over 1.5 million followers, but they represent less than $5 \%$ of the total. In the case of Instagram, the most-followed journalists have around 370 thousand followers $(2.7 \%$ of the total).

An in-depth analysis of the differences in the level of use of the two social media platforms reveals that those who work on TV have a significantly higher number of followers than those in other media outlets, particularly print media $(F=9.710 ; d f=3 ; p=.001 ; M=77,021$ for Twitter; $F$ $=7.852 ; d f=3 ; p=.001 ; M=1,598$ for Instagram), likely due to the higher level of exposure of the former (Tables 1 and 2).

\section{Table 1. Twitter followers by media type}

\begin{tabular}{|c|c|c|c|c|}
\hline Followers & Print (\%) & Online (\%) & Radio (\%) & Television (\%) \\
\hline $\mathbf{5 0 0}$ or less & 27 & 34.8 & 16 & 12.8 \\
\hline $\mathbf{5 0 1}-\mathbf{1 , 0 0 0}$ & 27 & 24.4 & 9.2 & 17.5 \\
\hline $\mathbf{1 , 0 0 1 - 1 0 , 0 0 0}$ & 42.9 & 34.9 & 47.2 & 43.6 \\
\hline $\mathbf{1 0 , 0 0 1 - 5 0 , 0 0 0}$ & 2.7 & 4.7 & 18.9 & 12.8 \\
\hline $\mathbf{5 0 , 0 0 1 - 1 0 0 , 0 0 0}$ & 0 & 1.2 & 2.4 & 3 \\
\hline $\mathbf{1 0 0 , 0 0 0}$ or more & .4 & 0 & 6.3 & 10.3 \\
\hline Total & 100 & 100 & 100 & 100 \\
\hline
\end{tabular}

Source: Own elaboration

Table 2. Instagram followers by media type

\begin{tabular}{|c|c|c|c|c|}
\hline Followers & Print (\%) & Online (\%) & Radio (\%) & Television (\%) \\
\hline $\mathbf{5 0 0}$ or less & 49.2 & 40.9 & 38.2 & 25.7 \\
\hline $\mathbf{5 0 1 - 1 , 0 0 0}$ & 28.6 & 33.3 & 24.1 & 26.2 \\
\hline $\mathbf{1 , 0 0 1 - 5 , 0 0 0}$ & 19 & 24.3 & 25.3 & 23.8 \\
\hline $\mathbf{5 , 0 0 1 - 1 0 , 0 0 0}$ & 1.6 & 0 & 3.1 & 3.5 \\
\hline $\mathbf{1 0 , 0 0 1 - 5 0 , 0 0 0}$ & 1.6 & 1.5 & 7.4 & 13.9 \\
\hline $\mathbf{5 0 , 0 0 1}$ or more & 0 & 0 & 1.9 & 6.9 \\
\hline Total & 100 & 100 & 100 & 100 \\
\hline
\end{tabular}

Source: Own elaboration 
Concerning the social media activity levels of Chilean journalists, the data show three groups of similar size. While $30.6 \%$ and $30.3 \%$ of Instagram and Twitter accounts, respectively, have low activity levels, $36.5 \%$ of journalists' Instagram accounts and $34.7 \%$ of their Twitter accounts show a medium level of activity and $32.9 \%$ and $35 \%$, respectively, high activity levels. ${ }^{7}$ Journalists with more followers show significantly higher levels of activity on their accounts, and vice versa (Spearman's Rho $=.351 ; p=.01$ for Twitter; Spearman's Rho $=.503 ; p=.01$ for Instagram).

\section{Identity construction}

Journalists can customize various features of their social media accounts and profiles depending on each platform's structural and contextual affordances (Hermida \& Mellado, 2020). The decisions that journalists make regarding each of these functionalities show how they build their brands and endeavor to make their digital identities (in)visible.

One of the first decisions a journalist must make when creating a social media account is whether to upload a profile picture and which image to use. This study shows that practically all Chilean news professionals personalize their Twitter (99.5\%) and Instagram (99.2\%) accounts using this resource. Furthermore, 9 out of 10 journalists appear in their Twitter or Instagram profile images. In analyzing the data according to the type of media for which the journalists work, we identified no significant differences for Instagram $\left(X^{2}=.193 ; d f=3 ; p=n s\right)$ but did find such variations for Twit$\operatorname{ter}\left(X^{2}=15.701 ; d f=3 ; p=.001\right)$. In the case of Twitter, while $4.3 \%$ and $7.8 \%$ of TV and radio journalists do not appear in their profile picture, respectively, this percentage increases to $14.5 \%$ for print journalists.

Besides, both Twitter and Instagram allow users to create a biography (also known as bio). A bio may indicate how familiar journalists are with the different customization tools available to them on social media. It also speaks to how important it is for each journalist to introduce themselves to their audiences. Our data show that $93.9 \%$ of journalists on Twit-

7 The activity of each account was classified using a three-level scale based on the number of posts made by the journalist on each network in the six months leading up to this study. 
ter and $73.5 \%$ on Instagram have bios. There is an important correlation between posting a bio and the intensive use of Twitter and Instagram. Journalists with medium and high activity levels are more prone to use bios. While the difference between low and high activity users is close to $7 \%$ on Twitter $\left(X^{2}=14.415 ; d f=3 ; p=.001\right)$, the rate for Instagram is $30.2 \%\left(\mathrm{X}^{2}\right.$ $=37.002 ; d f=3 ; p=.001)$.

Most Chilean journalists have a Spanish language bio (93.1\% on Twitter and $88.2 \%$ on Instagram). Those who only use English are mainly on Instagram ( $4.6 \%$ versus $1.7 \%$ on Twitter). They are likely appealing to interaction with international followers in the micro digital sphere that this platform creates.

Furthermore, only $2.6 \%$ of Chilean journalists' Twitter accounts and $2.9 \%$ of their Instagram accounts are verified, which means that the platform has validated their identity. Verification serves as a kind of recognition of their content being of public interest and can even confer a "celebrity" status in the context of those platforms.

An essential aspect of how journalists use their social media accounts to interact with the medium is whether they allow followers to contact them directly. The results are different from what we expected to find. On Twitter, a social media platform commonly considered helpful for reporting purposes, only 2 out of 10 journalists allow audience members to contact them via direct messages (15.7\%). Furthermore, just $2.2 \%$ publish their email addresses, and only .6\% use both channels. On Instagram, while there is no option to block direct messages, most journalists also publish their emails $(83.2 \%)$, phone numbers $(11 \%)$, or both $(5.8 \%)$.

Another unique feature of Instagram is that it offers users the option to turn their traditional account into a business account, which gives them access to more information about audiences, metrics, and interactions. Business account users also have easy access to promotional tools. Our analysis suggests that just $8.8 \%$ of the Chilean journalists on Instagram use this option and that most of them work on the radio or TV. 


\section{Differentiated Twitter and Instagram profiles}

In general, the data show that Chilean journalists use each social media platform uniquely. Our results suggest that $80.4 \%$ do not use the same profile picture on Twitter and Instagram and that $96.4 \%$ have different biographies, creating unique identifies for themselves.

Chilean journalists exhibit advanced levels of expertise with the affordances that each platform offers, particularly Twitter. For example, 72.6\% of these professionals use geolocation to show where they live or work or to share their location at a given time. An equally considerable percentage of journalists $(78.1 \%)$ use banner images to customize their profiles. The percentages of professionals who use hashtags $(9.1 \%)$ or links $(36.2 \%)$ in their biographies are markedly low.

Journalists with medium and high levels of activity tend to use all the functionalities offered by Twitter. Online journalists use geolocation in their profiles less frequently than the rest of their colleagues. Hashtag use is higher among radio and TV journalists than among print and online professionals, while print journalists use links in biographies much less than their colleagues in other types of media outlets (Table 3 ).

\section{Table 3. Use of Twitter technical affordances}

\begin{tabular}{|c|c|c|c|c|c|c|c|c|}
\hline & $\begin{array}{c}\text { Geolocation } \\
(\%)\end{array}$ & $\begin{array}{c}\text { Banner } \\
(\%)\end{array}$ & $\begin{array}{l}\text { Hashtags } \\
\text { in bio }(\%)\end{array}$ & $\begin{array}{l}\text { Link in } \\
\text { bio (\%) }\end{array}$ & $\begin{array}{c}\text { Journalist } \\
\text { in profile } \\
\text { picture } \\
(\%)\end{array}$ & $\begin{array}{c}\text { Journalist } \\
\text { with bio } \\
\text { (\%) }\end{array}$ & $\begin{array}{l}\text { Warnings } \\
\text { in bio (\%) }\end{array}$ & $\begin{array}{c}\text { Pinned } \\
\text { tweet (\%) }\end{array}$ \\
\hline & \multicolumn{8}{|c|}{ By gender } \\
\hline Men & 72.6 & 78.6 & 10.6 & 36.4 & 81.1 & 95.2 & 8.4 & 18.7 \\
\hline \multirow[t]{2}{*}{ Women } & 72.4 & 77.5 & 6.7 & 36 & 95 & 94.4 & 7 & 18.2 \\
\hline & \multicolumn{8}{|c|}{ By level of activity } \\
\hline Low & 65.5 & 68.2 & 4.7 & 22.6 & 90.4 & 90.6 & 6.2 & 9.4 \\
\hline Medium & 78.3 & 80.9 & 10.4 & 36.9 & 91.8 & 97 & 7.3 & 17.6 \\
\hline \multirow[t]{2}{*}{ High } & 73.1 & 84.4 & 11.1 & 46.4 & 89.9 & 97 & 9.2 & 27.9 \\
\hline & \multicolumn{8}{|c|}{ By media type } \\
\hline Print & 70.5 & 73.8 & 5.5 & 30.8 & 85.5 & 93.3 & 7.7 & 17.1 \\
\hline Online & 63.9 & 76.7 & 2.5 & 39 & 89.3 & 94.2 & 4.9 & 20.9 \\
\hline Radio & 75.4 & 80.6 & 11.1 & 40.8 & 92.2 & 96.1 & 7.6 & 18 \\
\hline Television & 72.6 & 81.2 & 13.4 & 36.9 & 95.7 & 95.7 & 9.4 & 19.7 \\
\hline
\end{tabular}

Source: Own elaboration 
Hashtag and bio link use on Instagram is similar. The percentage of journalists who use links in their bios is like that on Twitter (34.6\%). The same is true for hashtags, with $11.8 \%$ of journalists using this functionality.

Rates of use of Instagram affordances varied; $26.5 \%$ of journalists posted highlighted stories (pinning a video or image that would otherwise be deleted after 24 hours), and only $4.7 \%$ used Instagram TV, allowing content creators to upload videos lasting up to one hour. Thus, Chilean journalists (even those who work on television) do not tend to create lengthy audiovisual content for social media platforms, posting still images or short videos instead (Table 4).

As is the case with Twitter, users with medium and high activity levels use the platform's tools more frequently. Specifically, online journalists use hashtags in their biographies significantly more than journalists working in other types of media $\left(X^{2}=16.914 ; d f=3 ; p=.01\right)$. Radio and TV journalists include links referring to their news media sites, websites, or other social media accounts more frequently than print and online journalists $\left(X^{2}\right.$ $=12.299 ; d f=3 ; p=.05$ ).

Table 4. Use of Instagram technical affordances

\begin{tabular}{|c|c|c|c|c|c|c|c|c|c|c|}
\hline & $\begin{array}{c}\text { Highlighted } \\
\text { stories (\%) }\end{array}$ & $\begin{array}{c}\text { Instagram } \\
\text { TV (\%) }\end{array}$ & $\begin{array}{c}\text { Both } \\
(\%)\end{array}$ & $\begin{array}{c}\text { Hashtags } \\
\text { in bio (\%) }\end{array}$ & $\begin{array}{c}\text { Link in } \\
\text { bio (\%) }\end{array}$ & $\begin{array}{c}\text { Journalist } \\
\text { in profile } \\
\text { picture }\end{array}$ & $\begin{array}{c}\text { Journalist } \\
\text { with bio }\end{array}$ & $\begin{array}{c}\text { Warnings } \\
\text { in bio }\end{array}$ \\
\hline Men & 23.5 & .5 & 4.6 & 13.9 & 31.8 & 92.6 & 72 & .4 \\
\hline Women & 37.1 & 2 & 5.2 & 8.9 & 38.4 & 96 & 75.7 & 1.1 \\
\hline & & \multicolumn{7}{|c|}{ By gender } \\
\hline Low & 38.7 & 0 & 2.7 & 11.6 & 46.4 & 91.8 & \multicolumn{2}{|c|}{62.2} & 0 \\
\hline Medium & 53 & 2.3 & 3.8 & 15.9 & 29.2 & 93.9 & 85.6 & .9 \\
\hline High & 53.8 & 3.4 & 18.5 & 14.5 & 48.2 & 94.1 & 92.4 & .9 \\
\hline & & & \multicolumn{7}{|c|}{ By level of activity } \\
\hline Print & 26.5 & 1.1 & 3.7 & 6.8 & 29.5 & 93.6 & 69.8 & .8 \\
\hline Online & 33.3 & 1.5 & 6.1 & 3.9 & 51 & 93.9 & 77.3 & 0 \\
\hline Radio & 27.8 & 2.5 & 3.7 & 12.2 & 37.1 & 93.8 & 71 & 1.7 \\
\hline Television & 30.7 & 0 & 7.3 & 18.2 & 31.6 & 94.6 & 73.5 & 0 \\
\hline
\end{tabular}

Source: Own elaboration 


\section{Journalists and digital identity}

Beyond personalization elements such as profile pictures and biographies, journalists develop specific professional identities through their social media accounts. Analyzing their profiles offers a glimpse into how they portray themselves as individuals and can help us determine whether their profession is a critical element of their digital identity as it is presented to their audiences. Those decisions are linked to different levels of professional, organizational, or personal branding; that is, the different levels of effort journalists put into introducing and positioning themselves as relevant professional figures individually or at the news media level or highlighting some aspect of their personal lives.

One key element of this analysis is whether the journalists' profile pictures depict them more professionally or personally. The data reveal that journalists do not tend to identify themselves as such in their profile pictures but appear more professional on Twitter than on Instagram. Indeed, $18.8 \%$ of the Twitter profile pictures show journalists in their professional contexts, while this is only true in $9.8 \%$ of cases on Instagram.

The results also reveal that the types of images used by journalists vary significantly based on the types of media outlets for which they work. TV and radio journalists tend to project an image linked to their professional life on both Twitter $\left(X^{2}=58.187 ; d f=3 ; p=.001\right)$ and Instagram $\left(X^{2}=\right.$ $42.440 ; d f=3 ; p=.001)$. Online journalists engage in this type of identification in less than $2 \%$ of cases (Table 5 ).

\section{Table 5. Profile picture in a professional context by media type}

\begin{tabular}{|c|c|c|}
\hline & Twitter (\%) & Instagram (\%) \\
\hline Print & 7.8 & 1.6 \\
\hline Online & 1.3 & 13.9 \\
\hline Radio & 23.6 & 18.2 \\
\hline TV & 31.3 & 0 \\
\hline
\end{tabular}

Source: Own elaboration 
The data show that the focus of the biographies used by Chilean journalists is more personal on Instagram and more professional on Twitter, at least in the biography displayed in their profiles (Table 6).

Table 6. Journalist's biographies focus

\begin{tabular}{|c|c|c|}
\hline & Twitter (\%) & Instagram (\%) \\
\hline Mainly professional & 43.1 & 59.3 \\
\hline Mainly personal & 42.5 & 11.4 \\
\hline Both (balanced) & 14.4 & 59.3 \\
\hline
\end{tabular}

Source: Own elaboration

The results also reveal that media professionals in Chile tend to introduce themselves explicitly as journalists in their biographies, more than in their profile pictures. While 6 out of 10 introduce themselves as journalists on Instagram, 8 out of 10 do so on Twitter. Radio (64.7\%) and television (73.6\%) journalists' Instagram accounts present higher levels of identification with the profession in their biographies than journalists from print $(50.8 \%)$ and online media $(52.9 \%)\left(X^{2}=18.308 ; d f=3 ; p=.001\right)$, which may be because physical exposure is a crucial element of the daily routine of journalists who work in these media. The differences observed on Twitter are associated with journalists' activity levels, though it does not seem to be an obvious result at first glance $\left(X^{2}=20.753 ; d f=3 ; p=.001\right)$.

Journalists who use Twitter less intensely identify more with the profession through their accounts than those who use it more frequently $(82.9 \%$, compared to $73.2 \%)$. One possible interpretation of this phenomenon is that those who use their accounts the most tend to have more followers and may not feel the need to explain what they do for a living. Another possibility is that those who make their profession explicit are subject to more virtual scrutiny, a situation that more active users might want to avoid, given the risk of online trolling or harassment. Only $11.9 \%$ and $13.1 \%$ of journalists list their occupation in their Twitter and Instagram biographies, respectively. 
Despite the importance of news beats in the profession, only $12.9 \%$ of journalists list them on Twitter, and just $6.6 \%$ do so on Instagram. We did not find significant differences in this area based on gender or activity level, but we did according to media type. For example, in the case of Twitter, print journalists $(22.6 \%)$ list their news beats much more frequently than their colleagues who work on TV ( $8 \%)$, online $(7.4 \%)$, and on the radio $(9.1 \%)\left(X^{2}=31.159 ; d f=3 ; p=.001\right)$. Traditionally, print media have had a divisional structure. Despite massive layoffs, print outlets in Chile still have newsroom sizes that allow journalists to focus exclusively on specific beats, which may explain why this information is more important to them than for colleagues working in other types of outlets.

Another relevant point to discuss is how journalists' social media accounts are linked to the news outlet for which they work and their engagement with media branding, as practices designed to promote the work of news organizations. Journalists can link/mention their employers in their bios or refer to them in their profile pictures. Overall, the data show that journalists are less likely to perform organizational branding and more likely to practice professional branding in their profiles. All the journalists included in the study tend to use Twitter more than Instagram to engage in media branding. As previously suggested, radio and TV journalists tend to identify significantly more with the media for which they work in their profile pictures in both social media platforms $\left(X^{2}=28.255 ; d f=3 ; p=.001\right.$ for Instagram; $X^{2}=28.140 ; d f=3 ; p=.001$ for Twitter) (Table 7).

\section{Table 7. Media identification in the journalists' profile picture}

\begin{tabular}{|c|c|c|}
\hline & Twitter (\%) & Instagram (\%) \\
\hline \multicolumn{3}{|c|}{ By media type } \\
\hline Print & 7.3 & 0 \\
\hline Online & 1.2 & 0 \\
\hline Radio & 13.2 & 10.3 \\
\hline Television & 17.5 & 2.7 \\
\hline \multicolumn{2}{|c|}{ By activity level } \\
\hline Medium & 7 & 12.9 \\
\hline High & 12.4 & 7.6 \\
\hline
\end{tabular}

Source: Own elaboration 
Simultaneously, journalists whose Instagram accounts exhibit higher activity levels tend to identify more with their respective media organizations in their profile pictures $\left(X^{2}=10.675 ; d f=2 ; p=.001\right)$. Other than profile pictures, some journalists choose to identify with the media outlet where they work through their Twitter and Instagram biographies. Like the case above, radio and TV journalists perform this type of media branding more frequently. While nearly half of the television $(51.6 \%)$ and radio (44.3\%) journalists mention their employer in their Instagram biographies, only $13.7 \%$ and $21.2 \%$ of online and print journalists do the same $\left(X^{2}=\right.$ 47.921; $d f=3 ; p=.001)$. On Twitter, more journalists mention their employers, though the trends are similar, with a more substantial presence of $\mathrm{TV}(62.9 \%)$ and radio journalists $(61.6 \%)$ than online $(32.1 \%)$ and print $(48.7 \%)$ professionals $\left(X^{2}=32.455 ; d f=3 ; p=.001\right)$.

Journalists also express their organizational identities by linking their media outlets to their biographies, thus creating a bridge between those organizations and their followers. This analysis reveals that while most journalists include links in their bios, most direct users to personal sites (such as other personal social media accounts) and not to the media outlets' sites. Most of the accounts that do include a link to the media outlets are on Twitter.

\section{Discussion}

Based on a content analysis of 1,400 Twitter and Instagram accounts of 792 Chilean journalists, this study offers a first look at how Chilean media professionals use social media and respond to new demands for transparency, authenticity, and interaction on those platforms. In general, we found that Chilean journalists who work for national media organizations are professionals connected to the digital world, at least in their presence and activity levels on Twitter and Instagram. Over $90 \%$ of journalists have at least one active account on Twitter or Instagram, which indicates a high level of penetration of both platforms in this professional group. It is important to note that this penetration level is even higher than that found in previous studies conducted in the region. Besides, a medium or high level of use of both social media platforms was found in most journalists, meaning that they post at least once a day on Twitter and once a week on Instagram on average. 
While journalists use Twitter to open themselves up to the public (with a marginal percentage of private accounts), Instagram is just the opposite: more than half of the accounts are private, where journalists themselves create a more intimate connection with audiences. Nevertheless, most Chilean newspeople avoid communicating with their followers through private channels such as direct messages, emails, or phone calls, particularly on Twitter. A higher number of followers (and thus higher exposure levels) may create a greater need to protect themselves from attacks, trolling, or other negative experiences.

Regarding the number of followers, the audiences of journalists who work for national media outlets are larger on Twitter and tend to be heterogeneous and small, particularly on Instagram. At the same time, the professionalization of their social media through official verification is very low. Though they belong to a profession in which authorship of information is fundamental, the low presence of verified accounts on Twitter and Instagram might be linked to the low correlative numbers of followers, a lack of awareness of this tool, or even disinterest in using this feature, which confers more status and possibly more credibility to the account, along with greater responsibility.

As noted in the Results section, business accounts allow users to access advanced metrics, which means that they can gather data on the effectiveness of their posts. Our data reflects that only $8.8 \%$ of the journalists with an active Instagram account use such tools, and most of them work on television and the radio, suggesting that roles such as promoter or celebrity are emerging in journalistic practices in this platform (Mellado \& Hermida, 2021).

Following the distinction made by Ottovordemgentschenfelde (2017), the data also indicate that Chilean journalists strongly identify with their profession, which manifests mainly in their social media biographies. They reveal an explicit professional identity made visible through different functionalities that customize their accounts, particularly on Instagram. However, they tend to use their profile pictures to show themselves in personal contexts rather than their professional milieu. They also connect and 
engage with their audiences this way, exposing lifestyles and personalities that may be like those of regular citizens, humanizing themselves, and creating more robust transparency and authenticity ties.

The use that journalists make of verbal and visual elements to project an individual professional image instead of identifying with their news media organizations and their organizational identity is comparatively higher, particularly for online and print journalists and those with fewer followers. The instability of the job market in the field and the fact that many works for more than one media organization may influence these results. Indeed, cultivating many followers in social media may give journalists symbolic power that protects them from unemployment and may grant them a sort of immunity within their organizations, creating a pact (often implicit) between the news organization and the journalist. On the one hand, media branding allows journalists to showcase and promote their news organizations, increasing their profile level, the value of their social media use, and audience engagement. On the other, high profile social media accounts can become critical to the development and survival of media outlets' business, which gives the journalists who own those accounts more internal autonomy and security.

There are several possible explanations for the differences between Twitter and Instagram use by Chilean journalists. First, it is vital to consider the age of each platform. The fact that Twitter was created first may explain its larger audience sizes, how comfortable journalists are using the platform for professional purposes, and how much of their personal lives and identities they expose in their accounts. Second, we should emphasize the type of content that each platform privileges. Although both platforms promote the communication of "moments," Twitter does this mainly through short texts and exchanging current information of public interest. Instagram achieves this by sharing images and offers an experience that is primarily designed to be mobile. As a result, the platform is ideal for sharing the daily aspects of the news creation process, behind-the-scenes images from the newsroom, or information about journalists' personal lives. Journalists may use Twitter for traditional professional purposes and Instagram to develop emerging journalistic roles and as a space for self-expression. 
Although Twitter is usually linked to traditional journalistic work, we should highlight the significant opportunities for audience growth that Chilean journalists have on Instagram, which has nearly five times as many users as Twitter and a more cross-cutting target audience. This study does not analyze the content of journalists' posts, but we could see specific roles emerging in their online activity (Table 8 ).

\section{Table 8. Differences in Chilean journalists' use of Twitter and Instagram}

\begin{tabular}{|c|c|}
\hline Twitter & Instagram \\
\hline $2.3 \%$ of the accounts are private. & $54.5 \%$ of the accounts are private. \\
\hline Four out of 10 journalists have less than 1,000 followers. & $\begin{array}{c}\text { Nearly } 7 \text { out of } 10 \text { journalists have less than } 1,000 \\
\text { followers. }\end{array}$ \\
\hline $\begin{array}{c}\text { The most followed journalists have around 1,500,000 } \\
\text { followers. }\end{array}$ & $\begin{array}{l}\text { The most followed journalists have around 50,000 } \\
\text { followers. }\end{array}$ \\
\hline $7.9 \%$ write warnings on their biographies. & About $1 \%$ write warnings on their biographies. \\
\hline $\begin{array}{l}18.8 \% \text { of profile pictures show journalists in a professional } \\
\text { context. }\end{array}$ & $\begin{array}{l}9.8 \% \text { of profile pictures show journalists in a professional } \\
\text { context. }\end{array}$ \\
\hline $\begin{array}{l}\text { Two out of } 10 \text { journalists use different options (phone, } \\
\text { email) to contact audiences other than the feature } \\
\text { predetermined by the platform. }\end{array}$ & $\begin{array}{l}\text { Nearly } 90 \% \text { of journalists publish their email on their } \\
\text { accounts, besides the DM feature predetermined by the } \\
\text { platform. }\end{array}$ \\
\hline
\end{tabular}

Source: Own elaboration

Another critical side of this study is the influence that the type of media outlet where the journalists work has on the different identities deployed in their accounts. Gulyas (2013) found this to be the case in Western European countries as well, which strongly marks journalists' social media activity and levels of personal and professional branding on Twitter and Instagram. The highest levels of individual and organizational branding were observed among radio and TV journalists. In contrast to colleagues who work for print and online media outlets, social media use by TV journalists tends to be strongly influenced by this variable, possibly due to the higher levels of physical exposure associated with work on TV and radio. In this sense, the higher their follower count is, the more they tend to privilege their professional affiliation, which may be related to creating a personal brand. 
Furthermore, the penetration and success that television still enjoys in Chile may be connected to the dominance of this type of journalist on Twitter and Instagram in terms of audience size. Television journalists seem to use social media as a second screen that reinforces their audiovisual work when they have "no screen time" in traditional media.

It is important to note that this study is one of the first to map how Chilean journalists use their Twitter and Instagram accounts and the identities that emerge in these settings. As such, it also has several limitations. First, since our study only analyzes journalists' profiles and not their posts, we could not explore the specific practices they follow in their communication with audiences. Future studies should compare the professional practices of Chilean journalists on Twitter and Instagram using tweets or posts as units of analysis.

Second, although this study covers most of the national Chilean news media landscape, it does not include freelance journalists or those who work for local outlets. Therefore, their reality is not represented here. Similarly, when creating their accounts and designing their social media profiles, this topic should also be addressed through qualitative experiences such as digital ethnography to understand journalists' decision-making better.

Finally, given that this study shows how social platforms are associated with the emergence of new journalistic habits and roles in a specific country, future research should engage in in-depth studies of these dynamics in other societal contexts.

\section{References}

Brems, C., Temmerman, M., Graham, T., \& Broersma, M. (2017). Personal Branding on Twitter: How employed and freelance journalists stage themselves on social media. Digital Journalism, 5(4), 443-459.

Edelman. (2019) Edelman Trust Barometer 2019. https://www.edelman. com/sites/g/files/aatuss 191/files/2019-02/2019_Edelman_ Trust_Barometer_Global_Report.pdf 
Gulyas, A. (2013). The influence of professional variables on journalists' uses and views of social media: A comparative study of Finland, Germany, Sweden and the United Kingdom. Digital Journalism, 1(2), 270-285. https://doi.org/10.1080/21670811.2012.744559

Grubenmann, S., \& Meckel, M. (2015). Journalists' Professional Identity. Journalism Studies, 18(6), 732-748. https://doi.org/10.1080/14 61670X.2015.1087812

Hedman, U. (2016). When Journalists Tweet: Disclosure, Participatory, and Personal Transparency. Social media + society, 1-13. https:// doi.org/10.1177/2056305115624528

Hermida, A. (2010). Twittering the news: the emergence of ambient journalism. Journalism Practice, 4(3), 297-308. https://doi. org/10.1080/17512781003640703

Hermida, A. (2013). \#Journalism: Reconfiguring journalism research about Twitter, one tweet at a time. Digital Journalism, 1(3), 295-313. https://doi.org/10.1080/21670811.2013.808456

Hermida, A \& Mellado, C. (2020). Dimensions of Social Media Logics: Mapping Forms of Journalistic Norms and Practices on Twitter and Instagram. Digital Journalism 8(7), 864-884. DOI: https:// doi.org/10.1080/21670811.2020.1805779

Holton, A. E. \& Lewis, S. E. (2011). Journalists, social media, and the use of humor on Twitter. The Electronic Journal of Communication, 21 (1-2).

Lasorsa, D. L., Lewis, S. C., \& Holton, A. E. (2012). Normalizing Twitter: Journalism practice in an emerging communication space. Journalism studies, 13(1), 19-36. https://doi.org/10.1080/146167 0X.2011.571825

Mellado, C. (2012). The Chilean journalist. In Weaver, D \& Wilnat, L (eds) The Global Journalist in the 21st Century: News People Around the World. Routledge (pp. 382-399). 
Mellado, C., \& van Dalen, A. (2017). Challenging the Citizen-Consumer Journalistic Dichotomy: A News Content Analysis of Audience Approaches in Chile. Journalism \& Mass Communication Quarterly, 94(1),213-237.https://doi.org/10.1177/1077699016629373

Mellado, C. \& Hermida, A. (2021). The Promoter, Celebrity, and Joker Roles in Journalists' Social Media Performance. Social Media + Society, 7(1), 1-11. https://doi.org/10.1177/2056305121990643

Mellado, C., Salinas, P., Del Valle, C., \& González, G. (2010). Estudio comparativo de cuatro regiones: mercado laboral y perfil del periodista. Cuadernos.info, (26), 45-64. https://doi.org/10.7764/cdi.26.11

Mourao, R., \& Harlow, S. (2017, May). Awareness, Reporting, and Branding: Exploring Brazilian Journalists' Social Media Use Across Platforms [Paper presentation]. ICA, San Diego, CA, United States.

Noguera-Vivo, J. M. (2013). How open are journalists on Twitter? Trends towards the end-user journalism. Comunicación y Sociedad, 26(1), 93-114.

Olausson, U. (2017). The Reinvented Journalist: The discursive construction of professional identity on Twitter. Digital Journalism, 5(1), 61-81. https://doi.org/10.1080/21670811.2016.1146082

Ottovordemgentschenfelde, S. (2017). Organizational, professional, personal: An exploratory study of political journalists and their hybrid brand on Twitter. Journalism, 18(1), 64-80. https://doi. org/10.1177/1464884916657524

Powers, M., \& Vera-Zambrano, S. (2017). How journalists use social media in France and the United States: Analyzing technology use across journalistic fields. New Media \& Society, 20(8), 2782-2774. https://doi.org/10.1177/1461444817731566 
Saldaña, M., Schmitz, A., \& Calmon, R. (2017). Sharing the Stage. Analysis of social media adoption by Latin American journalists. Journalism Practice, 11(4), 396-416. https://doi.org/10.1080/17512 786.2016.1151818

Tandoc, E. C., \& Vos, T. P (2016). The Journalist is Marketing the News. Journalism Practice, 10(8), 950-966. https://doi.org/10.1080/17 512786.2015.1087811

Van Dijck, J. (2013). The culture of connectivity. Oxford University Press. https://doi.org/10.1093/acprof:oso/9780199970773.001.0001

Weiss, A. S. (2015). The digital and social media journalist: A comparative analysis of journalists in Argentina, Brazil, Colombia, Mexico, and Peru. International Communication Gazette, 77(1), 74-101.https:// doi.org/10.1177/1748048514556985

Willnat, L., \& Weaver, D. (2018). Social Media and US Journalists. Digital Journalism, 6(7), 889-909. https://doi.org/10.1080/2167081 1.2018 .1495570 